\title{
Determining unthinned shortleaf pine (Pinus echinata Mill.) plantation economic rotation ages in the Western Gulf
}

\begin{abstract}
Shortleaf pine (Pinus echinata Mill.) has been planted in the Western Gulf region. The Forest Vegetation Simulator (FVS) is the only widely available comprehensive yield prediction system for these plantations. Predictions from the time-of-planting were obtained for densities of 300,500 , and 700 for site indexes of 50,60, 70, and $80 \mathrm{ft}$ (base age 25). Based on verification analyses conducted using observed yields from other studies, FVS projections conducted from the time-of-planting are relatively low. Hence, additional verification analyses were made based on reported diameter distribution and associated height data in 10 year old plantations. "Calibrated" projections were then made for ages ranging from 15 to 40 . In general, if plot data are available, allowing FVS to be "calibrated" to local site conditions, much more accurate predictions will be produced. In terms of economics, given current markets, economic rotation ages are generally around 40 to 50 years. For low quality sites (e.g. site index $50 \mathrm{ft}$ ) financial returns will likely not be positive and hence on these lower quality sites an ecologically based management regime may be better.
\end{abstract}

Keywords: plantations, ecology, wildlife, wood products industry, ecosystem, timber production, forests, vegetation, biological diversity
Volume 2 Issue 3 - 2018

\author{
VanderSchaaf CL,' Michael Blazier, ${ }^{2}$ Eric \\ McConnell,' Joshua P Adams' \\ 'School of Agricultural Sciences and Forestry, Louisiana Tech \\ University, USA \\ ${ }^{2}$ School of Renewable Natural Resources, Louisiana State \\ University, USA
}

\begin{abstract}
Correspondence: VanderSchaaf CL, Assistant Professor, School of Agricultural Sciences and Forestry, Louisiana Tech University, Ruston, LA 7|272, USA, Tel (318) 257-2168, Email vandersc@latech.edu
\end{abstract}

Received: April 13, 2018| Published: May 07, 2018

\section{Introduction}

Shortleaf pine (Pinus echinata Mill.) is native to much of northern Louisiana, southern Arkansas, southeastern Oklahoma, and East Texas. ${ }^{1}$ According to the Shortleaf Pine Initiative (http://shortleafpine. net/), shortleaf was often found in open woodlands in both pine dominated and mixed pine-oak forests where sunlight reached the ground and a diverse assortment of native wildlife flourished. Over the last 30 years, this extensive shortleaf pine ecosystem has lost over $50 \%$ of its former acreage. Massive pine beetle outbreaks in poorly managed stands, changes in timber management practices, altered fire regimes, disease, and land use changes have contributed to this rapid decline. These forested landscapes represent an extraordinary diversity of cultural, ecological and economic values centered on wildlife and recreation, water quality, and a high-value wood products industry.

Coordinated efforts are beginning to restore the shortleaf pine ecosystem such as by groups like the Shortleaf Pine Initiative. Although over story woody vegetation is a major component of the restoration effort, the ecosystem provided many other components such as understory vegetation, biological diversity, wildlife habitat, recreation, etc. The restoration process of this ecosystem will likely begin through the use of plantations. Managers need tools to examine how different management options will likely impact financial returns. One factor is planting density across a variety of site productivity levels. Planting density is important because it will impact future economic returns that will help to offset costs associated with the restoration process. Although a more open woodland setting may be the ultimate goal by most agencies in these plantations, timber production will help to offset the initial conversion and regeneration costs. Additionally, partners wanting to restore and/or manage for components of the ecosystem such as wildlife, water quality, etc., will benefit from knowing how stand development will occur over time to identify how these forests can be used to provide their desired services.

According to a recent Forest Inventory and Analysis (FIA) estimate ${ }^{2}$ within the state of Arkansas there are 72,221 acres, within the state of Louisiana there are no plantations, within the state of Oklahoma there are 17,117 acres, and within the state of Texas there are 1,602 acres of plantations. The majority of acres in Arkansas are in the northwestern part of the state. Due to the long-term nature of tree growth, it will be quite some time before results from actual field trials established to quantify growth and yield in relation to various management options will be available. Hence, growth and yield models that predict how forests will grow over time will initially be used to help managers identify optimal planting densities.

Several studies ${ }^{3-5}$ have found that shortleaf pine generally has slower growth rates relative to the more often planted loblolly (Pinus taeda L.) and slash pine (Pinus elliottii Engelm). However, it generally is considered to outgrow the two other pines by age 40 or 50 and hence this species will likely have longer rotations. Identifying the economic returns of shortleaf pine relative to those from loblolly and slash pine will help landowners to determine the trade-off between how much financial return they may sacrifice to help restore this ecosystem. Shortleaf does have some forest management potential relative to loblolly and slash pine such as better stem form that will increase volume production and it is particularly resistant to fusiform rust 
(Cronartiium quercuum f. sp. fusiforme). Additionally, this species is generally less susceptible to the negative effects of ice, snow, and cold temperatures relative to the other major southern pines and it can produce higher standing basal areas per acre.

Yield tables have been published for shortleaf pine in the Western Gulf Coastal Plain region. Murphy \& Beltz ${ }^{6}$ presented yield tables for naturally-regenerated stands in the Coastal Plain. Yields of unevenaged shortleaf pine stands were presented in Murphy \& Farrar $^{7}$ Huebschmann MM et al., ${ }^{8}$ developed a yield prediction system for uneven-aged stands in Arkansas. Basal area equations were developed by Budhathoki $\mathrm{CB}$ et al., ${ }^{9}$ for naturally-regenerated even-aged stands in Arkansas and Oklahoma. Few equations exist to predict plantation development in the Western Gulf. The Southern variant (SN, version 1860) of Forest Vegetation Simulator (FVS) covers forest areas in the southern United States including Arkansas, Louisiana, East Texas, and Mississippi ${ }^{10,11}$ and can be used to predict shortleaf pine stand development. SN model relationships were fit in the early 2000s using Forest Inventory and Analysis (FIA) periodic inventory data from all Southern states. This is a distance-independent individual tree model.

The objectives of this study were to quantify financial returns of unthinned plantations when using growth and yield projections from FVS and to gain insight into optimal economic rotation ages. Verification analyses of the FVS projections using published data were also conducted to help determine the validity of the economic analyses. Beyond quantifying economic returns, these results can also be used to determine when these restored forests may provide habitat for other desired benefits from the ecosystem.

\section{Materials and methods}

Within SN, the "Bareground" option was used to generate plantations of 300,500 , and 700 seedlings/acre. Survival at age one was assumed to be $100 \%$ and the "Sprouting" option was turned off to eliminate natural regeneration. Unlike the Southeastern variant, the MANAGED keyword is not available for shortleaf in the Southern variant. The FVS keyword MANAGED is used to reflect that in general plantations have greater diameter growth rates relative to natural or "unmanaged" stands.

Minimum merchantability limits were consistent with standard FVS SN protocol and stump height was set to $1 \mathrm{ft}$. Minimum merchantable pulpwood diameter at breast height ( $4.5 \mathrm{ft}$ about ground level, DBH) was 4.0 in, and upper stem diameter inside-bark (DIB) was 4.0 in. Chip-n-saw specifications were minimum $\mathrm{DBH}$ of 9.0 in and a DIB of 4.0 in. Sawtimber specifications were minimum DBH of 12.0 in and a DIB of $7.0 \mathrm{in}$. Volumes were calculated using the SpMcDBH keyword within FVS.

Base stumpage values per green ton for pine pulpwood, chip-nsaw, and sawtimber were $\$ 10, \$ 19$, and $\$ 25$, respectively, and were obtained from the $3^{\text {rd }}$ quarter, 2017 Louisiana Timber Market Report. ${ }^{12}$ Three other sets of revenues were also examined-relatively high pulpwood market (\$20 per ton) with the base chip-n-saw and sawtimber revenues, relatively high chip-n-saw market (\$29 per ton) with the base pulpwood and sawtimber revenues, and a relatively high saw timber market ( $\$ 40$ per ton) with the base pulpwood and chip-n-saw revenues. It was assumed there are 63 pounds per green cubic $\mathrm{ft}$ of wood. Discounted regeneration costs were assumed to be \$250/acre-e.g. costs for seedlings, site preparation, herbaceous weed control, etc.

The default FVS max Stand Density Index (SDI) of 435 was used. Site index equations within FVS use a base age of 50 . However, projections were desired based on site indices using a more common base age of 25 . Hence, site indices (base age $50 \mathrm{yr}$ ) of $80,98,113$, and $132 \mathrm{ft}$ were specified within FVS to produce site indices of 50, 60,70 , and $80 \mathrm{ft}$ (base age $25 \mathrm{yr}$ ), respectively. All future reference to site index assumes a base age of 25 years. FVS keyword STDINFO was used to specify the stand being located in the Kisatchie National Forest (Kisatchie). Projections were obtained for planting densities of 300,500 , and 700 stems/acre for site indexes of 50,60,70, and $80 \mathrm{ft}$ (base age 25). Hence, there were twelve "base" model runs.

\section{Results and discussions}

Consistent with expectations as site quality and planting density increase standing basal area/acre and total merchantable cubic $\mathrm{ft}$ volume increase (Figure 1). Essentially planting densities of 500 and 700 seedlings/acre reach a constant basal area/acre asymptote for a particular site quality.

1. There are three types of verification analyses (Table 1) comparing predictions from FVS to published amounts:

a) "Base" model where only planting density and site index were specified within FVS, no inventory data was used to help "calibrate" FVS to local site conditions.

b) Calibrated FVS projections where stand table (or number of trees by diameter class) information by diameter classes were entered to help calibrate projections to local site conditions.

c) Calibrated FVS projections where stand table information by diameter and height classes were entered to help calibrate projections to local site conditions.

\section{"Base" model verification analyses}

"Base" model verification analyses compare published basal area and volume estimates to those from FVS when simply specifying planting density and site index.

\section{Basal area}

Growth and yield studies across the southeastern US were compared to projections from FVS (Table 1). The first study is from north central Mississippi ${ }^{13}$ in a plantation established at a density of 691 seedlings/acre. Average heights of dominant and codominant trees at age 25 years were reported as $67 \mathrm{ft}$. FVS projections from the 700 planting density and for a site index of $70 \mathrm{ft}$ were used. According to this study, FVS vastly under-predicts stand development up to age 25 years. However, values reported by Williston HL et al., ${ }^{13}$ are based on research plots where trees likely received much greater care. For instance, survival at age 15 years was $100 \%$. Data used in developing FVS are from USDA Forest Service Forest Inventory and Analysis (FIA) data that are obtained across a variety of regeneration and management intensities.

Comparisons were also made among FVS and yields presented in a publication entitled Yield Tables and Stand Structure for Shortleaf Pine Plantations in Tennessee, Alabama, and Georgia Highlands. ${ }^{14}$ 
Basal area for site indexes of 50 and $60 \mathrm{ft}$ (base age 25 years) were compared for a planting density of 750 seedlings/acre from Smalley \& Bailey $^{14}$ using the 700 seedlings/acre FVS projections. At ages of 30 years and younger, FVS underpredicted but by age 40 years projections were similar to those reported.

\section{Basal Area Per Acre}

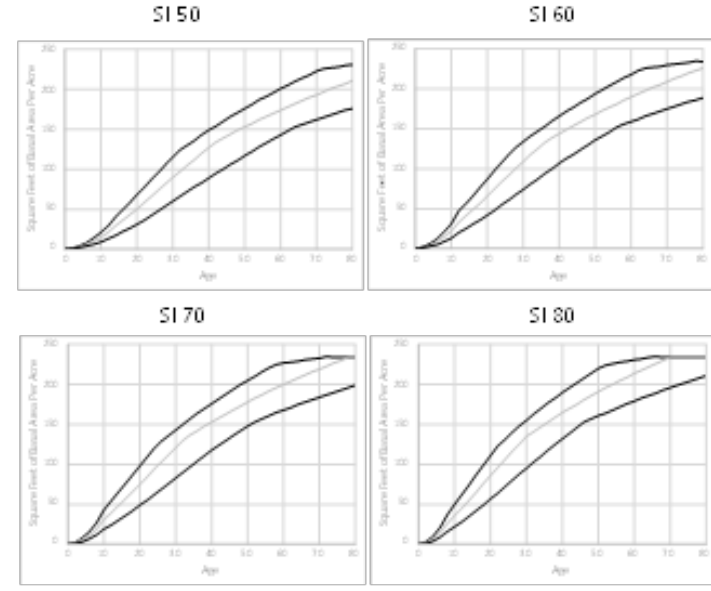

\section{Cubic Foot Volume Per Acre}

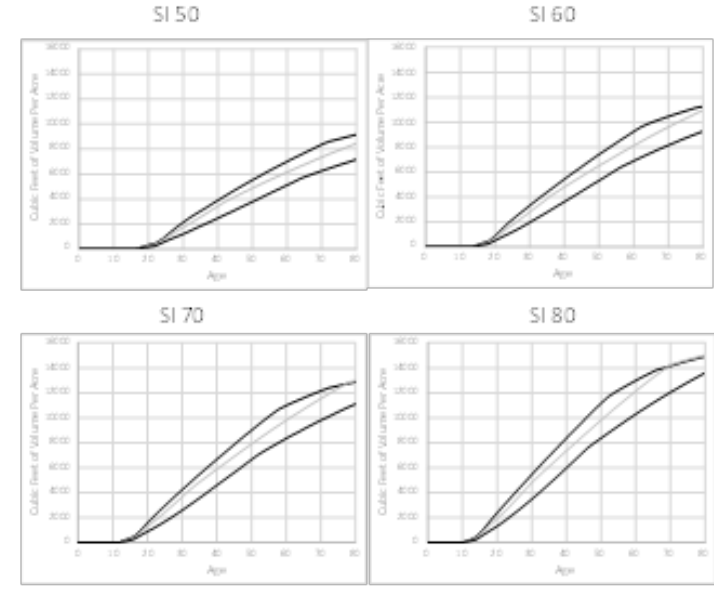

Figure I Basal area and total merchantable cubic foot volume (minimum DBH of 4 in to a 4 in top DIB) projections by planting density ( 300,500 , and 700 seedlings per acre) and site index (50,60,70, and $80 \mathrm{ft}$-base age 25$)$. The black bold lines are projections for 700 seedlings per acre, gray lines are projections for 500 seedlings per acre, and black lines are projections for 300 seedlings per acre.

Table I Observed basal area and volume per acres from Williston $\mathrm{HL}$ et al., ${ }^{13}$ and Smalley \& Bailey ${ }^{14}$ FVS are projections obtained using FVS as conducted during this study

\begin{tabular}{|c|c|c|c|c|}
\hline \multirow[b]{2}{*}{$\begin{array}{l}\text { Method/age } \\
\text { (years) }\end{array}$} & \multicolumn{2}{|c|}{$\begin{array}{l}\text { Basal area/acre } \\
\text { (sq ft/acre) }\end{array}$} & \multicolumn{2}{|c|}{$\begin{array}{l}\text { Volume/acre } \\
\text { (cu ft/acre) }\end{array}$} \\
\hline & Observed & FVS & Observed & FVS \\
\hline \multicolumn{5}{|c|}{ Williston HL et al. ${ }^{13}$} \\
\hline 10 & 99 & 43 & 765 & 0 \\
\hline 15 & 147 & 71 & 1995 & 301 \\
\hline 25 & 162 & 125 & 4,120 & 2,951 \\
\hline \multicolumn{5}{|c|}{ Smalley \& Bailey ${ }^{14}$} \\
\hline \multicolumn{5}{|l|}{ Site index 50} \\
\hline 10 & 71 & 21 & 177 & 0 \\
\hline 15 & 134.7 & 45 & 850 & 1.5 \\
\hline 20 & 147.4 & 68 & $\mathrm{I}, 573$ & 312 \\
\hline 30 & 153.1 & 115 & 2,745 & $2,|2|$ \\
\hline 40 & 152.9 & 149 & 3,383 & 3,892 \\
\hline \multicolumn{5}{|l|}{ Site index 60} \\
\hline 10 & 92.2 & 31 & 398 & 0 \\
\hline 15 & 131.6 & 61 & $|, 4| \mid$ & 186 \\
\hline 20 & 152.7 & 87 & 2,377 & 878 \\
\hline 30 & 163 & 134 & 3,666 & 3,331 \\
\hline 40 & 157.5 & 166 & 4,257 & 5,443 \\
\hline
\end{tabular}

$\begin{array}{lllll}10 & 71 & 71 & 177 & 502 \\ 15 & 112.1 & 91 & 850 & 888 \\ 20 & 134.7 & 108 & 1,573 & 1,310 \\ 30 & 153.1 & 137 & 2,745 & 2,182 \\ 40 & 152.9 & 160 & 3,383 & 2,974 \\ \text { Site Index 60 } & & & & \\ 10 & 92.2 & 92 & 398 & 915 \\ 15 & 131.6 & 114 & 1,411 & 1,531 \\ 20 & 152.7 & 130 & 2,377 & 2,099 \\ 30 & 163 & 158 & 3,666 & 3,307 \\ 40 & 157.5 & 184 & 4,257 & 4,408\end{array}$

Smalley \& Bailey ${ }^{14}$ : Calibrated using diameter and height Site index 50

$\begin{array}{lllll}10 & 71 & 71 & 177 & 306 \\ 15 & 112.1 & 95 & 850 & 535 \\ 20 & 134.7 & 115 & 1,573 & 1,189 \\ 30 & 153.1 & 149 & 2,745 & 2,710 \\ 40 & 152.9 & 176 & 3,383 & 4,213 \\ \text { Site index 60 } & & & \\ 10 & & 92 & 398 & 485 \\ 15 & 92.2 & 116 & 1,411 & 990 \\ 20 & 131.6 & 133 & 2,377 & 1,650 \\ 30 & 152.7 & 162 & 3,666 & 3,183 \\ 40 & 163 & 188 & 4,257 & 4,653\end{array}$




\section{Merchantable cubic foot volume}

For the study in Mississippi, ${ }^{13}$ reported cubic foot volumes to a 3 in DIB and for all trees in DBH greater than 4 in when compared to estimates from FVS show that FVS underestimates volumes at ages 10,15 , and 25 years, respectively. However, FVS does estimate volume to a 4 in top DIB and this would likely explain some of the underestimation. However, basal area is also underestimated and hence in general FVS probably underpredicts volume when compared to those volumes reported as part of this study.

Comparisons among FVS and volumes presented in Smalley \& Bailey ${ }^{14}$ for a planting density of 750 seedlings/acre showed similar results as for basal area. Cubic foot volumes within Smalley \& Bailey ${ }^{14}$ were defined as inside-bark for all trees with DBHs greater than 5 in and up to a 4 in DOB. Site index 50 and $60 \mathrm{ft}$ sites showed that FVS in general underpredicts but that by age 30 years FVS produces similar results and actually by age 40 years FVS exceeds the published amounts. A caveat of all merchantable volume comparisons is that FVS uses an upper-stem 4 in DIB while Smalley and Bailey use a 4 in DOB upper-stem merchantability limit. Hence, some of the under prediction when using FVS can be explained.

These verification analyses show that FVS likely predicts slower development of shortleaf pine plantations than may be observed

\section{Base Revenues}

5150

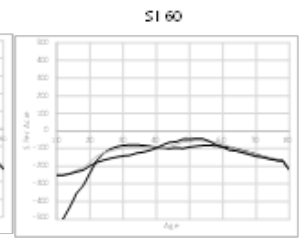

5170

sI 20

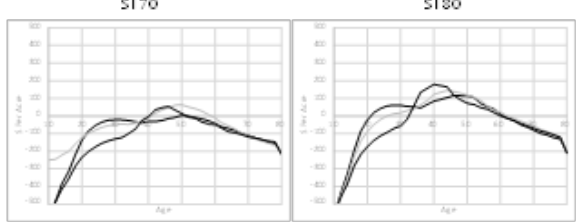

Strong Chip-n-Saw Market

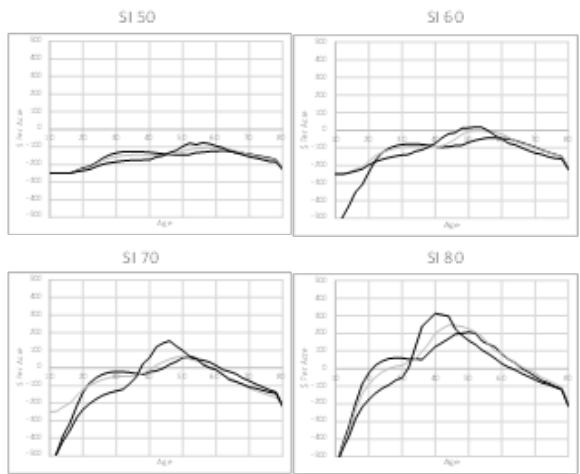

operationally and hence likely results in predicting longer rotation ages than may be observed operationally given current market conditions. Nonetheless, FVS is a useful tool to begin discussions about likely economic rotation ages and how these plantations may develop for those stands that will be managed more for habitat restoration. These simple verification analyses use base FVS estimates, or those from time-of-planting. If stand, diameter, and height information can be obtained from plots in the field, FVS can be calibrated for those site conditions. Calibrated predictions may be better.

\section{Financial analyses of base model verification}

For current stumpage markets, rotation ages are generally around 40 to 50 years (Figure 2). These are much longer than common rotation ages for loblolly and slash pine. For higher quality sites (e.g. site index $80 \mathrm{ft}$ ) a planting density of around 300 seedlings/ acre should be implemented but for moderate quality sites planting densities of around 500 seedlings may produce better returns. These differences are likely due to variability in the proportion of relatively high value chip-n-saw material. For low quality sites (e.g. site index $50 \mathrm{ft}$ ) financial returns will likely not be positive and hence these sites should not be managed if economic returns are the overriding concern. If ecological restoration of this habitat type is the overriding concern of an agency, they may want to manage these lower quality sites exclusively for those purposes.

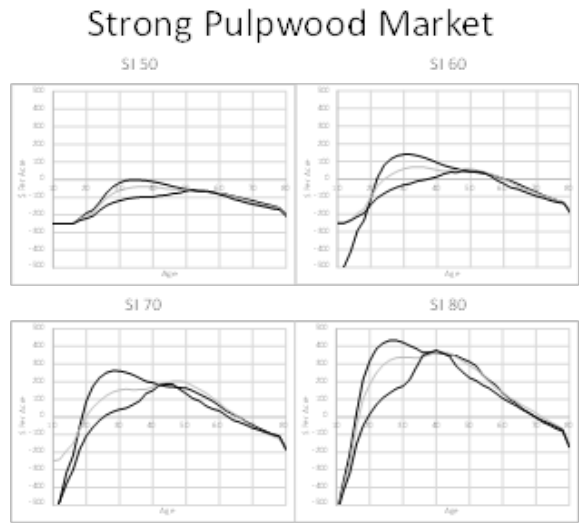

Strong Sawtimber Market

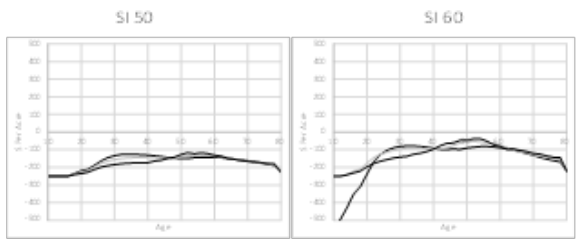

170

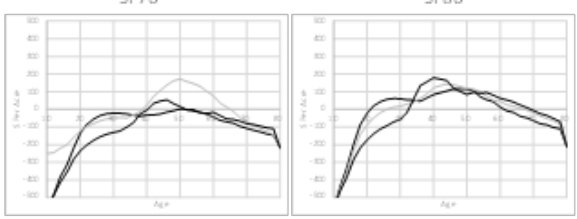

Figure 2 Dollars per acre (Soil Expectation Value) projections by planting density $(300,500$, and 700 seedlings per acre) and site index ( $50,60,70$, and $80 \mathrm{ft}-$ base age 25) using the base revenues of $\$ 10, \$ 19$, and $\$ 25$ per ton for the pulpwood, chip-n-saw, and sawtimber product classes, respectively (Base), using the base revenues but a pulpwood revenue of $\$ 20$ per ton when there is a strong pulpwood market, a revenue of $\$ 29$ per ton for chip-n-saw when there is a strong chip-n-saw market, and a revenue of $\$ 40$ per ton for sawtimber when there is a strong sawtimber market. The black bold lines are projections for 700 seedlings per acre, gray lines are projections for 500 seedlings per acre, and black lines are projections for 300 seedlings per acre. 
If a very strong pulpwood market exists, rotation ages will be drastically shortened and planting densities should be higher. Optimum rotation ages are around 25 to 35 years. When chip-n-saw markets are relatively strong, results are similar to the base stumpage values. FVS does not predict a substantial amount of saw timber material to occur in these plantations for stand ages of around 40 to 60 years and hence rotation ages are not greatly impacted in areas where saw timber would have a strong competitive advantage. Although the lower planting density (300 seedlings/acre) on higher quality sites does produce a fair amount of saw log material this volume is produced at later ages and hence the discount factor reduces the impacts of the greater saw timber product class revenues.

\section{"Calibrated" model verification analyses using only observed diameters}

"Base" model verification analyses compare published basal area and volume estimates to those from FVS when simply specifying planting density and site index. However, if plot data are available FVS can be calibrated to those site characteristics that have generated the observed plot data. For instance, for a site index $60 \mathrm{ft}$ site planted at 750 seedlings/acre, Smalley \& Bailey ${ }^{14}$ present a stand and stock table at age 10 years. This data can be entered into FVS and "calibrated" projections can be obtained. Smalley \& Bailey ${ }^{14}$ also present basal area and yield estimates at ages $15,20,30$, and 40 years. For this "calibrated" analysis, a planting density of 750 was examined for site qualities of 50 and $60 \mathrm{ft}$ (base age 25 years). This was the lowest planting density presented by them. For these "calibrated" analyses height was not included, only the observed stand table was used to "calibrate" FVS to local site conditions. To produce site indexes of 50 and $60 \mathrm{ft}$, the SETSITE keyword used values of 42 and $57 \mathrm{ft}$ for the FVS Site index value or percent change: variable; respectively.

\section{Basal area}

Following calibration using only diameter, FVS basal area/acre estimates appear to be much better (Table 1). By age 30 years, FVS predicts similar amounts to those reported. By age 40 years FVS predicts greater amounts on both site qualities.

\section{Merchantable cubic foot volume}

FVS volume estimates appear to be much better following calibration using only diameter. By age 20 years FVS predicts similar amounts to those reported for both site qualities.

\section{Financial analyses of calibrated model verification}

For current stumpage markets, rotation ages are generally around 30 to 40 years (Figure 3 ). These are longer than common rotation ages for loblolly and slash pine. Higher quality sites will likely have shorter rotations. Given current markets, low quality sites may not produce any positive returns. If ecological restoration of this habitat type is the overriding concern of an agency, they may want to manage these lower quality sites exclusively for those purposes.

\section{Using Only Stand Table Data (number of trees by diameter class)}
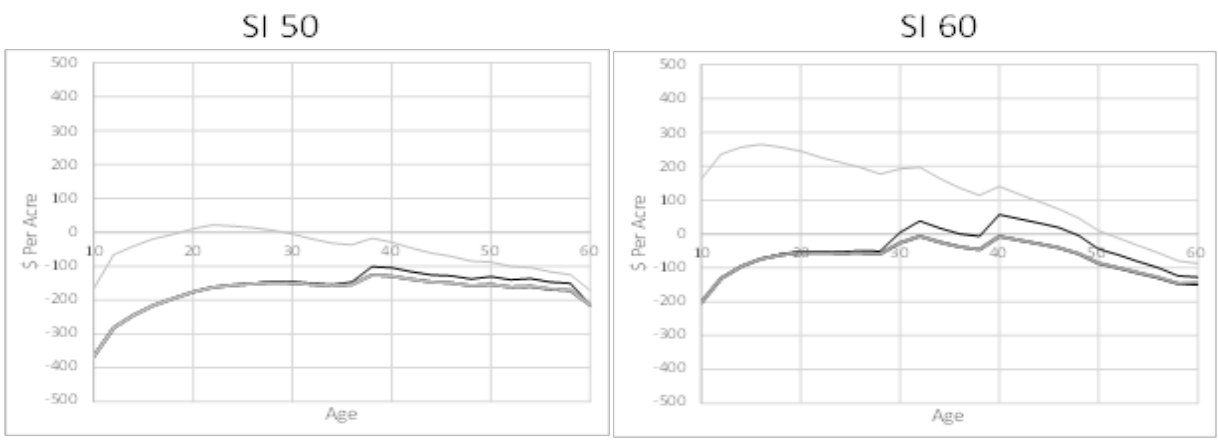

Using Both Diameter and Height by Diameter Class

SI 50

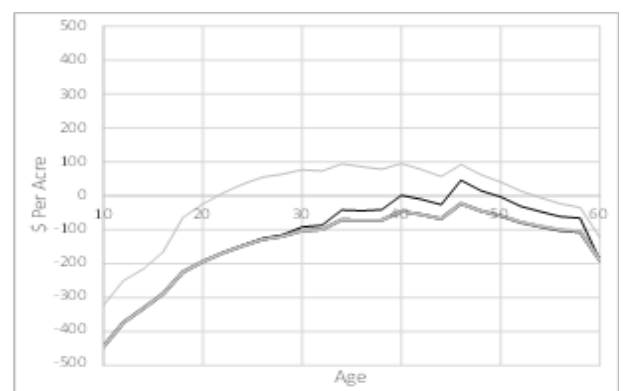

SI 60

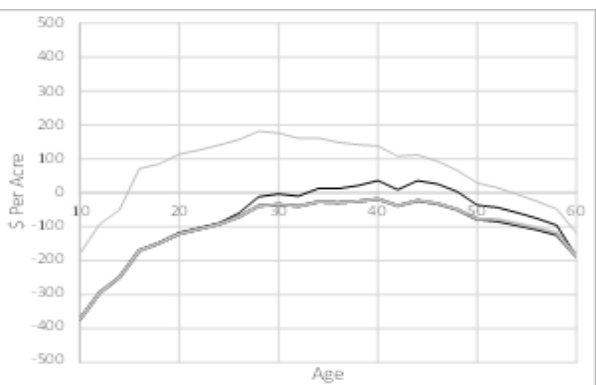

Figure 3 Dollars per acre (Soil Expectation Value) projections for a planting density of 750 seedlings per acre on site index 50 and 60 sites (base age 25$)$ using published stand table data (diameters only -UPPER) AND stand table data (diameters) and associated heights (LOWER) from Smalley \& Bailey ${ }^{14}$ of 10 year old plantations for calibration. Site index 50 on the left and site index 60 on the right. The gray line is when there are strong pulpwood markets (\$20/ton), the black line is when there are strong chip-n-saw markets ( $\$ 29 /$ ton), the gray bold line is when there are strong sawlog markets ( $\$ 40 /$ ton), and the black bold line are the current stumpage revenues ( $\$ 10 /$ ton for pulpwood, $\$ 19 /$ ton for chip- $n-$ saw, and $\$ 25 /$ ton for saw logs). The bold gray and bold black lines basically coincide with each other. 
Regardless of site quality, if a very strong pulpwood market exists rotation ages will be drastically shortened to around 15 to 25 years. When chip-n-saw markets are relatively strong optimal rotation ages are similar to the current market stumpage values on both site qualities, but become positive on the site index 60 sites. FVS does not predict a substantial amount of saw timber material to occur in these plantations for stand ages up to around 60 years and hence rotation ages are not predicted to be greatly impacted in those areas where saw timber would have a strong competitive advantage.

\section{"Calibrated" model verification analyses using observed diameters and heights}

For these "calibrated" analyses observed heights by diameter class in the observed stand tables were also used to "calibrate" FVS to local site conditions. For these analyses, unlike the diameter-only "calibration" analyses, the SETSITE keyword was not used to force a particular site index. Based on the observed heights, the site index used by FVS depends on how FVS calculated the value internally using the observed heights. Site indexes of 46 and $50 \mathrm{ft}$ (base age 25 years) were produced in FVS based on the observed heights for the site index 50 and $60 \mathrm{ft}$ sites from Smalley \& Bailey ${ }^{14}$ respectively.

\section{Basal area}

Following calibration using both height and diameter, FVS basal area/acre estimates appear to be much better relative to the "Base" runs (Table 1). By age 30 years FVS predicts similar amounts to those reported. By age 40 years FVS predicts greater amounts on both site qualities. When compared to calibrating using only diameters, calibrating using both diameters and heights does not appear to meaningfully improve basal area estimates.

\section{Merchantable cubic foot volume}

FVS volume estimates appear to be much better following calibration when compared to the "Base" runs. At age 30 years FVS predicts similar values to those reported but by age 40 years FVS overpredicts. When compared to using only diameter to calibrate, using both height and diameter generally produced inferior predictions. This may not always be true.

\section{Financial analyses of calibrated model verification}

For current stumpage markets, rotation ages are generally around 40 to 45 years (Figure 3 ). These are longer than common rotation ages for loblolly and slash pine. Higher quality sites will likely have shorter rotations. Given current markets, low quality sites may not produce any positive returns. If ecological restoration of this habitat type is the overriding concern of an agency, they may want to manage these lower quality sites exclusively for those purposes.

Regardless of site quality, if a very strong pulpwood market exists rotation ages will be drastically shortened to around 25 to 35 years. When chip-n-saw markets are relatively strong optimal rotation ages are similar to the current market stumpage values on both site qualities, but they become positive. FVS does not predict a substantial amount of sawtimber material to occur in these plantations for stand ages up to around 60 years and hence rotation ages are not predicted to be greatly impacted in those areas where sawtimber would have a strong competitive advantage.

\section{Conclusions}

Based on verification analyses, non-calibrated (or "Base") FVS projections likely underpredict stand development up to around age 30 years. After that, FVS may actually overpredict. Calibration using diameter and also diameter and height helped to produce more accurate estimates. These verification analyses show that in general FVS predicts slower stand development relative to those studies used in the verification process. Hence, using FVS to conduct economic analyses may result in longer rotations than would be observed operationally. A caveat of the financial analyses is that a 4 in top was used for pulpwood. In many markets a 2 in top can be used which would likely make the economic analyses look more attractive and may reduce rotation ages. Using alternative merchantable specifications may reduce rotation ages. However, FVS does not allow for smaller DIBs than 4 in.

FVS showed that given current markets optimal rotation ages across a range of site qualities will vary from around 30 to 45 years. These rotation ages are longer relative to those currently economically optimal for loblolly and slash pine. Optimal planting densities will likely vary to some extent across site qualities. FVS showed that on higher quality sites a planting density of around 300 seedlings/acre should be used but on moderate sites higher planting densities near 500 seedlings may be better. Obviously if pulpwood markets are strong locally, rotation ages will be reduced and planting densities should be increased. Given current markets, on lower quality sites (e.g. site index of $50 \mathrm{ft}$ and less) financial returns will likely be negative and hence on these lower quality sites an ecologically based management regime may be better. Future work will concentrate on using FVS to provide information about optimal thinning regimes.

\section{Acknowledgements}

None.

\section{Conflict of interest}

Author declares there is no conflict of interest.

\section{References}

1. Burns RM, Honkala BH. Silvics of North America: 1. Conifers. Agriculture Handbook 654. USA: US Department of Agriculture, Forest Service; 1990. p. 1-683.

2. Miles PD. Forest Inventory EVALIDator web-application Version 1.6.0.03. USA: US Department of Agriculture, Forest Service, Northern Research Station; 2017.

3. Williston HL. Shortleaf and loblolly pine growth in the mid-South. Journal of Forestry. 1972;70(5):290-291.

4. Schubert MR, Rennie JC, Schlarbaum SE. Four Pine Species Grown at Four Spacings on the Eastern Highland Rim, Tennessee, After 30 Years. Gen Tech Rep SRS-71. Asheville, USA: US Department of Agriculture, Forest Service, Southern Research Station; 2004. p. 433-436.

5. Lynch TB, Saud P, Dipesh KC, Will RE. Plantation site index comparisons for shortleaf pine and loblolly pine in Oklahoma, USA. Forest Science. 2016;62(5):546-552.

6. Murphy PA, Beltz RC. Growth and yield of shortleaf pine in the West Gulf Region. Res. Pap. SO-169. USA: US Department of Agriculture, Southern Forest Experiment Station; 1981. p. 1-20. 
7. Murphy PA, Farrar RM. Growth and yield of uneven-aged shortleaf pine in the Interior Highlands. USA: US Department of Agriculture, Southern Forest Experiment Station; 1985. p. 1-16.

8. Huebschmann MM, Gering LR, Lynch TB, et al. An individual-tree growth and yield prediction system for uneven-aged shortleaf pine stands. Southern Journal of Applied Forestry. 2000;24(2):112-120.

9. Budhathoki CB, Lynch TB, Guldin JM. Nonlinear mixed modeling of basal area growth for shortleaf pine. Forest Ecology and Management. 2008;255:3440-3446.

10. Dixon GE. Essential FVS: A user's guide to the Forest Vegetation Simulator. Internal Rep. Fort Collins, USA: US Department of Agriculture, Forest Service \& Forest Management Service Center; 2002. p. $1-246$.
11. Keyser CE. Southern (SN) Variant Overview-Forest Vegetation Simulator. Internal Rep. Fort Collins, USA: US Department of Agriculture, Forest Service, Forest Management Service Center. 2008. p. $1-87$.

12. Tanger SM. Louisiana Timber Market Report. USA: LSU Agricultural Center Research \& Extension; 2017.

13. Williston HL. Growth and yield of planted loblolly and shortleaf pines in a north Mississippi creek bottom. Southern Journal of Forestry. 1985;9(4):247-249.

14. Smalley GW, Bailey RL. Yield tables and stand structure for shortleaf pine plantations in Tennessee, Alabama, and Georgia Highlands. USA: US Department of Agriculture, Forest Service, Southern Forest Experiment Station; 1974. p. 1-61. 